\title{
Pengaruh Gaya Kepemimpinan Transaksional dan Gaya Kepemimpinan Transformasional terhadap Kinerja Karyawan dengan Komitmen Organisasi sebagai Variabel Moderating pada PT. Bangun Mitra Abadi Medan
}

\author{
Fauza Pratama ${ }^{1}$, Winda Ardiani ${ }^{2}$, Rizki Putra ${ }^{3}$ \\ ${ }^{1,2,3}$ Universitas Harapan Medan \\ fauzapratama012@gmail.com \\ windaardiani.chan@gmai.com \\ rizkyputrase@gmail.com
}

\begin{tabular}{l}
\hline ARTICLE DETAILS \\
\hline History \\
Received $\quad$ February \\
Revised Format $:$ March \\
Accepted $\quad$ April \\
\hline
\end{tabular}

Keywords : gaya kepemimpinan transaksional, gaya kepemimpinan transformasional, kinerja karyawan, komitmen organisasi

\begin{abstract}
S
Penelitian ini bertujuan untuk mengetahui pengaruh gaya kepemimpinan transaksional dan transformasional terhadap kinerja karyawan baik secara parsial maupun simultan. Untuk mengetahui apakah komitmen organisasi memoderasi pengaruh gaya kepemimpinan transaksional dan gaya kepemimpinan transformasional terhadap kinerja karyawan pada. Jumlah sampel sebesar 116 orang dengan menggunakan teknik regresi linier berganda dan MRA. Hasil penelitian menunjukkan bahwa gaya kepemimpinan transaksional dan gaya kepemimpinan transformasional berpengaruh terhadap kinerja karyawan secara parsial dam simultan. Komitmen organisasi terbukti signifikan dalam memoderasi gaya kepemimpinan transaksional terhadap kinerja karyawan serta komitmen organisasi terbukti signifikan dalam memoderasi gaya kepemimpinan transformasional terhadap kinerja karyawan.
\end{abstract}

\section{PENDAHULUAN}

Menciptakan sebuah gaya kepemimpinan transaksional yang mampu membawa para anggotanya untuk meningkatkan kinerja dalam rangka pencapaian tujuan organisasi bukanlah suatu hal yang mudah. Hal ini disebabkan karena pada dasarnya manusia memiliki karakteristik tingkah laku yang berbeda sesuai dengan tingkat kebutuhannya. Apabila terdapat perbedaan atau kesenjangan antara persepsi anggota dengan persepsi pimpinan mengenai iklim yang dirasakan dan yang diharapkan, maka ini akan memungkinkan terciptanya ketidakpuasan kerja dari anggota, sehingga dapat menimbulkan penyalahgunaan hak dan kewajiban yang akhimya mengakibatkan tujuan organisasi tidak dapat dipenuhi secara optimal. Persoalan-persoalan ini semakin bertumpuk dengan kecenderungan organisasi untuk berkembang, dan menyesuaikan diri dengan perkembangan lingkungan di sekitarnya sehingga anggota seringkali kehilangan identitas pribadi, dan pimpinan makin sulit untuk memuaskan kebutuhan anggota dan mencapai tujuan organisasi sekaligus.

Terdapat faktor-faktor negatif yang dapat menurunkan kinerja karyawan, diantaranya adalah menurunnya keinginan karyawan untuk mencapai prestasi kerja, kurangnya ketepatan waktu dalam penyelesaian pekerjaan sehingga kurang menaati peraturan, pengaruh yang berasal dari lingkungannya, teman sekerja yang juga menurun semangatnya dan tidak adanya contoh yang harus dijadikan acuan dalam pencapaian prestasi kerja yang baik. Dalam hal tersebut peran

*Corresponding Author Email Address: rizkyputrase@gmail.com 
seorang pemimpin menjadi juru kunci dalam membangun semangat bawahannya bekerja untuk mencapai tujuan perusahaan. Semua itu merupakan beberapa sebab menurunnya kinerja karyawan dalam bekerja. Seorang pemimpin harus menerapkan gaya kepemimpinan untuk mengelola bawahannya, karena seorang pemimpin akan sangat mempengaruhi keberhasilan organisasi dalam mencapai tujuannya. Gaya kepemimpinan adalah perilaku atau cara yang dipilih dan dipergunakan pemimpin dalam mempengaruhi pikiran, perasaan, sikap dan perilaku para anggota organisasi bawahannya (Nawawi, 2013).

Pada PT. Bangun Mitra Abadi Medan yang merupakan perusahaan swasta yang bergerak dalam bidang leveransir atau kontraktor, karyawannya dalam melaksanakan tugastugasnya selalu tergantung kepada pimpinan. Bila pimpinan tidak memiliki kemampuan memimpin, maka tugas-tugas karyawan yang sangat kompleks tidak dapat dikerjakan dengan baik. Apabila pimpinan mampu melaksanakan fungsi-fungsinya dengan baik, sangat mungkin PT. Bangun Mitra Abadi Medan dapat mencapai sasarannya. Berdasarkan hasil uraian di atas, maka penulis merasa tertarik memilih judul : "Pengaruh Gaya Kepemimpinan Transaksional dan Gaya Kepemimpinan Transformasional Terhadap Kinerja Karyawan dengan Komitmen Organisasi Sebagai Variabel Moderating Pada PT. Bangun Mitra Abadi Medan”.

\section{KAJIAN PUSTAKA}

\section{Kinerja}

Setiap karyawan dituntut untuk memberikan kontribusi positif melalui kinerja yang baik, mengingat kinerja organisasi tergantung pada kinerja karyawannya. Menurut Dessler (2016) kinerja karyawan merupakan prestasi kerja, yakni perbandingan antara hasil kerja yang dilihat secara nyata dengan standar kerja yang telah ditetapkan organisasi. Adapun indikator dari kinerja karyawan menurut Mas'ud (2014) adalah :

1. Kualitas

2. Kuantitas

3. Ketepatan Waktu

4. Efektifitas

5. Kemandirian

\section{Gaya Kepemimpinan Transaksional}

Menurut Maulizar et al (2012) bahwa kepemimpinan transaksional adalah model kepemimpinan dimana seorang pemimpin cenderung memberikan arahan kepada bawahan, serta memberi imbalan dan hukuman atas kinerja mereka serta menitik beratkan pada perilaku untuk memandu pengikut mereka ke arah tujuan yang ditetapkan dengan memperjelas peran dan tuntutan tugas.

\section{Gaya Kepemimpinan Transformasional}

Model kepemimpinan transformasional merupakan model yang relatif baru dalam studi-studi kepemimpinan. Konsep kepemimpinan transformasional mengintegrasikan ide-ide yang dikembangkan dalam pendekatan watak, gaya, dan kontingensi. Menurut Yukl (2010) "Kepemimpinan transformasional menyerukan nilai-nilai moral dari pada pengikut dalam upayanya untuk meningkatkan kesadaran mereka tentang masalah etis dan untuk memobilisasi energi dan sumber daya mereka untuk mereformasi institusi". Arif (2010) menyatakan komponen dari kepemimpinan transformasional terdiri atas empat dimensi kepemimpinan yaitu:

1. Idealized Influence (kharisma)

2. Inspirational Motivation (motivasi inspiratif)

3. Individual Consideration (konsiderasi individual)

4. Intellectual Stimulation (stimulasi intelektual)

5. Idealized Behaviours (tingkah laku) 


\section{Komitmen Organisasi}

Berdasarkan definisi dari Mathis dan Jackson (2010), komitmen organisasional adalah tingkat sampai di mana karyawan yakin dan menerima tujuan organisasi, serta berkeinginan untuk tetap tinggal di dalam organisasi tersebut. Tujuan organisasi sendiri merupakan perwujudan dari nilai-nilai yang digunakan dan diyakini oleh setiap anggota organisasi. Konsep komitmen pada organisasi yang tercantum dalam penelitian ini diadaptasi dari pendapat Lincoln dalam Sopiah (2014) yaitu meliputi :

1. Kemauan.

2. Kesetiaan.

3. Kebanggaan.

$\mathrm{H}_{1}$ : Gaya kepemimpinan transaksional berpengaruh positif terhadap kinerja pegawai pada PT. Bangun Mitra Abadi Medan.

$\mathrm{H}_{2}$ : Gaya kepemimpinan transformasional berpengaruh positif terhadap kinerja pegawai pada PT. Bangun Mitra Abadi Medan.

$\mathrm{H}_{3}$ : Komitmen organisasi memoderasi hubungan antara gaya kepemimpinan transaksional terhadap kinerja karyawan pada PT. Bangun Mitra Abadi Medan.

$\mathrm{H}_{4}$ : Komitmen organisasi memoderasi hubungan antara gaya kepemimpinan transformasional terhadap kinerja karyawan pada PT. Bangun Mitra Abadi Medan.

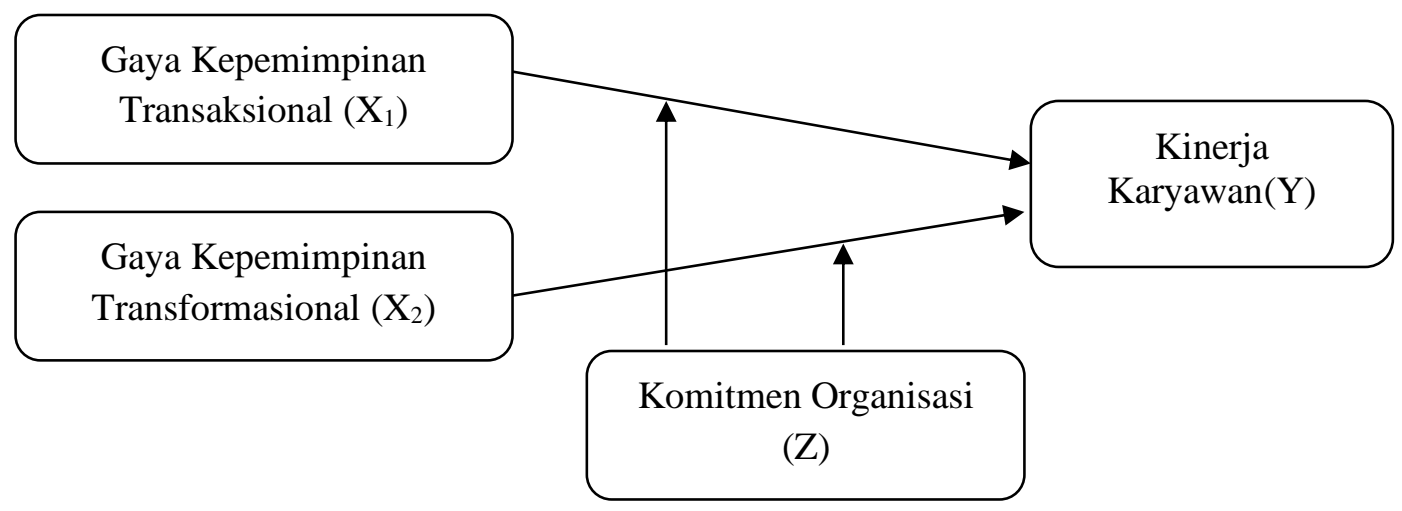

Sumber : Data diolah, 2020

\section{METODE PENELITIAN}

\section{Populasi dan Sampel Penelitian}

Populasi dalam penelitian ini adalah karyawan PT. Bangun Mitra Abadi Medan yang berjumlah 159 orang. Sampel yang digunakan dalam penelitian ini adalah 116 responden dengan menggunakan rumus Slovin, dengan teknik penariksan sampel adalah random sampling.

\section{Teknik Analisa Regresi Berganda}

Regresi berganda adalah model regresi atau prediksi yang melibatkan lebih dari satu variabel bebas atau prediktor. Istilah regresi berganda dapat disebut juga dengan istilah multiple regression. Kata multiple berarti jamak atau lebih dari satu variabel. Regresi linier berganda digunakan untuk mengetahui pengaruh variabel bebas (gaya kepemimpinan transaksional dan

gaya kepemimpinan transformasional) dengan variabel terikat (kinerja karyawan) dan analisis data menggunakan SPSS, rumusnya adalah sebagai berikut :

$$
\mathrm{Y}=\mathrm{a}+\mathrm{b}_{1} \mathrm{X}_{1}+\mathrm{b}_{2} \mathrm{X}_{2}+\varepsilon
$$




\section{Moderated Regression Analysis (MRA)}

\section{MRA I Hipotesis 3}

1. Persamaan 2

$$
\mathrm{Z}=\mathrm{a}+\mathrm{b}_{3} \mathrm{X}_{1}+\mathrm{e} 1
$$

2. Persamaan 3

$$
\mathrm{e}_{\mathrm{absolute}}=\mathrm{a}-\mathrm{b}_{4} \mathrm{Y}
$$

\section{MRA I Hipotesis 4}

1. Persamaan 4

$$
\mathrm{Z}=\mathrm{a}+\mathrm{b}_{5} \mathrm{X}_{2}+\mathrm{e} 1
$$

2. Persamaan 5

$\mathrm{e}_{\mathrm{absolute}}=\mathrm{a}-\mathrm{b}_{6} \mathrm{Y}$

\section{HASIL DAN PEMBAHASAN}

\section{Hasil Penelitian}

\begin{tabular}{|c|c|c|c|c|c|c|}
\hline & \multirow{2}{*}{ Model } & \multicolumn{2}{|c|}{$\begin{array}{c}\text { Unstandardized } \\
\text { Coefficients }\end{array}$} & \multirow{2}{*}{$\begin{array}{c}\begin{array}{c}\text { Standardized } \\
\text { Coefficients }\end{array} \\
\text { Beta }\end{array}$} & \multirow[b]{2}{*}{$\mathrm{t}$} & \multirow{2}{*}{ Sig. } \\
\hline & & B & $\begin{array}{l}\text { Std. } \\
\text { Error }\end{array}$ & & & \\
\hline \multirow{3}{*}{1} & (Constant) & 9,347 & 2,385 & & $\overline{3,918}$ & $\overline{0}, 000$ \\
\hline & Gaya Kepemimpinan Transaksional & ,235 &, 117 &, 195 & 2,004 & 047 \\
\hline & $\begin{array}{l}\text { Gaya Kepemimpinan } \\
\text { Transformasional }\end{array}$ & 211 & 098, & ,209 & 2,147 & 034, \\
\hline
\end{tabular}

Hasil Uji Hipotesis

Tabel 1. Hasil Uji t

a. Dependent Variable: Kinerja Karyawan

Nilai t-hitung untuk $\mathrm{X}_{1}$ menunjukkan bahwa nilai $\mathrm{t}_{\text {hitung }}<\mathrm{t}_{\text {tabel }}(2,004>1,981)$, yang berarti bahwa gaya kepemimpinan transaksional berpengaruh signifikan terhadap kinerja karyawan $(0.047<0.05)$. Sedangkan untuk $\mathrm{X}_{2}$, nilai t-hitung $>\mathrm{t}$-tabel $(2,147>1,981)$ yang berarti gaya kepemimipinan transformasional berpengaruh signifikan terhadap kinerja karyawan $(0.034<0.05)$.

Tabel 2. Hasil Uji F

\begin{tabular}{llccccc}
\hline & Model & Sum of & Df & Mean Square & F & Sig. \\
\hline 1 & Regression & 206,571 & 2 & 103,285 & 7,427 &, $001^{\mathrm{a}}$ \\
& Residual & 1571,464 & 113 & 13,907 & & \\
& Total & 1778,034 & 115 & & & \\
\hline
\end{tabular}

a. Predictors: (Constant), Gaya Kepemimpinan Transformasional, Gaya Kepemimpinan Transaksional

b. Dependent Variable: Kinerja Karyawan

Pengujian $\mathrm{F}$ dapat dilihat dari tabel ANOVA sebesar 7,427 dengan tingkat signifikan 0,001 . Jadi $F_{\text {hitung }}>F_{\text {tabel }}(7,427>3,08)$ dan Sig. $<5 \%(0,001<0,05)$. Artinya model ini telah fit dan dapat digunakan dalam penelitian ini.

Tabel 3. Hasil Uji Determinasi

\begin{tabular}{ccccc}
\hline Model & R & R Square & Adjusted R Square & Std. Error of the Estimate \\
\hline 1 &, 341 &, 116 &, 101 & 3,72918 \\
\hline
\end{tabular}

Dari Tabel di atas, diperoleh R Square untuk Y (kinerja karyawan) adalah 0,116. Hal ini berarti 11,6\% variasi variabel kinerja karyawan (Y) dipengaruhi oleh variabel $\mathrm{X}_{1}$ (gaya 
kepemimpinan transaksional) dan variabel $\mathrm{X}_{2}$ (gaya kepemimpinan transformasional) secara simultan dan sisanya sebesar $88,4 \%$ ditentukan oleh variabel lain di luar kontribusi penelitian ini.

\section{Moderated Regression Analysis}

MRA 1 (Hipotesis 3)

Persamaan Model 2

$$
Z=a+b_{3} X_{1}+e_{1}
$$

Tabel 4. Hasil Uji Regresi Persamaan Model 2

\begin{tabular}{|c|c|c|c|c|c|c|}
\hline & \multirow[t]{2}{*}{ Model } & \multicolumn{2}{|c|}{$\begin{array}{c}\text { Unstandardized } \\
\text { Coefficients }\end{array}$} & \multirow{2}{*}{$\begin{array}{c}\text { Standardized } \\
\text { Coefficients } \\
\text { Beta } \\
\end{array}$} & \multirow[t]{2}{*}{$\mathrm{t}$} & \multirow[t]{2}{*}{ Sig. } \\
\hline & & B & Std. Error & & & \\
\hline \multirow[t]{2}{*}{1} & (Constant) & $-1,299$ & 2,009 & &,- 646 &, 519 \\
\hline & $\begin{array}{l}\text { Gaya Kepemimpinan } \\
\text { Transaksional }\end{array}$ & 663, & ,095 & ,522 & 7,011 & ,000 \\
\hline
\end{tabular}

a. Dependent Variable: Komitmen Organisasi

$$
Z=-1,299+0,663 X_{1}
$$

a. Konstanta (a) $=-1.299$ menunjukkan harga konstan, dimana jika nilai variabel independen tetap, maka komitmen organisasi berkurang sebesar 1.299.

b. Koefisien $\mathrm{X}_{1}\left(\mathrm{~b}_{1}\right)=0.663$, menunjukkan bahwa variabel gaya kepemimpinan transaksional $\left(\mathrm{X}_{1}\right)$ berpengaruh positif dan signifikan terhadap komitmen organisasi $(\mathrm{Z})$ dan akan menambah komitmen organisasi sebesar 0.663 .

\section{Persamaan Model 3}

$\boldsymbol{e}_{\text {absolute }}=\mathbf{a}-\mathbf{b}_{4} \mathbf{Y}$

\begin{tabular}{|c|c|c|c|c|c|c|}
\hline & \multirow[t]{2}{*}{ Model } & \multicolumn{2}{|c|}{$\begin{array}{c}\text { Unstandardized } \\
\text { Coefficients }\end{array}$} & \multirow{2}{*}{$\begin{array}{l}\text { Standardized } \\
\text { Coefficients }\end{array}$} & \multirow[t]{2}{*}{$\mathrm{t}$} & \multirow[t]{2}{*}{ Sig. } \\
\hline & & B & Std. Error & & & \\
\hline \multirow[t]{2}{*}{1} & (Constant) & 5,047 &, 515 & & 9,803 & ,000 \\
\hline & $\begin{array}{l}\text { Kinerja } \\
\text { Karyawan }\end{array}$ &,- 165 & ,028 &,- 490 & $-5,997$ & ,000 \\
\hline
\end{tabular}

Tabel 5. Hasil Uji Regresi Persamaan Model 3

a. Dependent Variable: ebsolute1

Berdasarkan Tabel, menunjukkan nilai koefisien regresi sebesar - 0,165 dengan nilai signifikansi lebih kecil dari 0,05 yakni $0,000<0,05$. Dengan demikian dapat disimpulkan bahwa $\mathrm{H}_{3}$ diterima dan $\mathrm{H}_{0}$ ditolak yaitu komitmen organisasi memoderasi hubungan antara gaya kepemimpinan transaksional terhadap kinerja karyawan.

\section{MRA II (Hipotesis 4)}

Persamaan Model 4

$$
\mathbf{Z}=\mathbf{a}+\mathbf{b}_{4} \mathbf{X}_{2}+\mathbf{e}_{2}
$$

\begin{tabular}{|c|c|c|c|c|c|c|}
\hline & \multirow[t]{2}{*}{ Model } & \multicolumn{2}{|c|}{$\begin{array}{c}\text { Unstandardized } \\
\text { Coefficients }\end{array}$} & \multirow{2}{*}{$\begin{array}{c}\text { Standardized } \\
\text { Coefficients } \\
\text { Beta }\end{array}$} & \multirow[t]{2}{*}{$\mathrm{t}$} & \multirow[t]{2}{*}{ Sig. } \\
\hline & & $\mathrm{B}$ & Std. Error & & & \\
\hline \multirow[t]{2}{*}{1} & (Constant) & ,827 & 1,802 & & ,459 & ,647 \\
\hline & $\begin{array}{l}\text { Gaya Kepemimpinan } \\
\text { Transformasional }\end{array}$ & ,569 & ,086 & ,502 & 6,650 & ,000 \\
\hline
\end{tabular}

Tabel 6. Hasil Uji Regresi Persamaan Model 4

a. Dependent Variable: Komitmen Organisasi

$$
\mathrm{Z}=0,827+0,569 \mathrm{X}_{2}
$$


Persamaan Model 5

$\boldsymbol{e}_{\text {absolute }}=\mathbf{a}-\mathbf{b}_{5} \mathbf{Y}$

Tabel 7. Hasil Uji Regresi Persamaan Model 5

\begin{tabular}{llccccc}
\hline \multirow{2}{*}{ Model } & \multicolumn{2}{c}{ Unstandardized Coefficients } & \multicolumn{2}{c}{$\begin{array}{c}\text { Standardized } \\
\text { Coefficients }\end{array}$} & \multirow{2}{*}{$\mathrm{t}$} & \multirow{2}{*}{ Sig. } \\
\cline { 2 - 5 } & $\mathrm{B}$ & Std. Error & Beta & & \\
\hline 1 & (Constant) & 21,096 &, 619 & & 34,053 &, 000 \\
& ebsolute1 & $-1,324$ &, 248 &,- 447 & $-5,333$ &, 000 \\
\hline
\end{tabular}

a. Dependent Variable: Kinerja Karyawan

Berdasarkan Tabel, menunjukkan nilai koefisien regresi sebesar -1,324 dengan nilai signifikansi lebih kecil dari 0,05 yakni $0,000<0,05$. Dengan demikian dapat disimpulkan bahwa $\mathrm{H}_{4}$ diterima dan $\mathrm{H}_{0}$ ditolak yaitu komitmen organisasi memoderasi hubungan antara gaya kepemimpinan transformasional terhadap kinerja karyawan pada PT. Bangun Mitra Abadi Medan.

\section{Pembahasan}

\section{Pengaruh Gaya Kepemimpinan Transaksional Terhadap Kinerja Karyawan}

Berdasarkan hasil uji statistik diperoleh hasil bahwa gaya kepemimpinan transaksional berpengaruh positif dan signifikan terhadap kinerja karyawan. Menurut Maulizar et al. (2012) menyimpulkan bahwa kepemimpinan transaksional adalah model kepemimpinan dimana seorang pemimpin cenderung memberikan arahan kepada bawahan, serta memberi imbalan dan hukuman atas kinerja mereka serta menitik beratkan pada perilaku untuk memandu pengikut mereka ke arah tujuan yang ditetapkan dengan memperjelas peran dan tuntutan tugas. Hasil ini sejalan dengan hasil penelitian yang dilakukan oleh Maulizar et al. (2012), Hidayati (2014) yang menyatakan bahwa gaya kepemimpinan transaksional berpengaruh positif dan signifikan terhadap kinerja karyawan.

\section{Pengaruh Gaya Kepemimpinan Transformasional Terhadap Kinerja Karyawan}

Berdasarkan hasil uji statistik diperoleh hasil bahwa gaya kepemimpinan transformasional berpengaruh positif dan signifikan terhadap kinerja karyawan. Menurut Wijaya (2015) gaya kepemimpinan transformasional adalah pemimpin yang mampu mendatangkan perubahan di dalam diri setiap individu yang terlibat dan/atau bagi seluruh organisasi untuk mencapai kinerja yang semakin tinggi. Hasil ini sejalan dengan hasil penelitian yang dilakukan oleh Maulizar et al. (2012), Hidayati (2014), Subhi (2014), Mubarak et al (2015), Nurdin et al (2016) yang menyatakan bahwa gaya kepemimpinan transformasional berpengaruh positif dan signifikan terhadap kinerja karyawan.

\section{Pengaruh Gaya Kepemimpinan Transaksional Terhadap Kinerja Karyawan yang Dimoderasi oleh Komitmen Organisasi}

Berdasarkan hasil uji statistik diperoleh hasil bahwa komitmen organisasi memoderasi pengaruh gaya kepemimpinan transaksional terhadap kinerja karyawan. Gaya kepemimpinan transaksional menurut Robbins et al (2018) diukur dengan menjanjikan penghargaan untuk kinerja yang bagus dan mengakui pencapaian yang di peroleh, mengamati dan mencari penyimpangan dari aturan-aturan dan standar, serta melakukan tindakan perbaikan, melakukan perbaikan sistem apa bila standar tidak tercapai, dan memberikan kesempatan pada para bawahan untuk tanggung jawab pribadi. Hasil ini sejalan dengan hasil penelitian yang dilakukan oleh Hidayati (2014) yang menyatakan bahwa komitmen organisasi memoderasi pengaruh gaya kepemimpinan transaksional berpengaruh positif dan signifikan terhadap kinerja karyawan. 


\section{Pengaruh Gaya Kepemimpinan Transformasional Terhadap Kinerja Karyawan yang} Dimoderasi oleh Komitmen Organisasi

Berdasarkan hasil uji statistik diperoleh hasil bahwa komitmen organisasi memoderasi pengaruh gaya kepemimpinan transformasional terhadap kinerja karyawan. Luthans (2016) menyatakan bahwa kepemimpinan transformasional membawa keadaan menuju kinerja tinggi pada organisasi yang menghadapi tuntutan pembaharuan dan perubahan. Kepemimpinan transformasional merupakan kemampuan untuk memberikan inspirasi dan memotivasi para pengikutnya untuk mencapai hasil - hasil yang lebih besar daripada yang direncanakan secara.

\section{SIMPULAN DAN SARAN}

\section{Simpulan}

1. Gaya kepemimpinan transaksional berpengaruh signifikan terhadap kinerja karyawan pada PT. Bangun Mitra Abadi Medan.

2. Gaya kepemimipinan transformasional berpengaruh signifikan terhadap kinerja karyawan pada PT. Bangun Mitra Abadi Medan.

3. Komitmen organisasi memoderasi hubungan antara gaya kepemimpinan transaksional terhadap kinerja karyawan pada PT. Bangun Mitra Abadi Medan.

4. Komitmen organisasi memoderasi hubungan antara gaya kepemimpinan transformasional terhadap kinerja karyawan pada PT. Bangun Mitra Abadi Medan.

\section{Saran}

1. Hendaknya perusahaan memperhatikan kemampuan karyawan untuk mengenal diri sendiri dimana faktor pengenalan diri sendiri akan memudahkan karyawan untuk meningkatkan potensi dirinya baik demi kepentingannya maupun di lingkungan kerjanya. Semakin baik baik gaya kepemimpinan transaksional yang diterapkan, maka kemungkinan besar dapat meningkatkan kinerja karyawan.

2. Gaya kepemimpinan transformasional yang diharapkan dari diri karyawan akan lebih baik lagi apabila dilaksanakan dengan pemahaman akan karakteristik dan kondisi kerja secara efektif dan efisien.

3. Perilaku karyawan dalam melaksanakan tugas sesuai dengan standar perusahaan akan mencerminkan perusahaan tempatnya bekerja.

\section{DAFTAR PUSTAKA}

Arif, Rusdan. (2010). Pengaruh Kepemimpinan Dan Budaya Organisasi Terhadap Kinerja Karyawan (Studi pada PT. Bank Mega Cabang Semarang). Skripsi S-1 Fakultas Ekonomi Manajemen. Universitas Diponegoro Semarang.

Dessler, Gary. (2016). Manajemen Personalia. Teknik dan Konsep Modern. Diterjemahkan oleh : Agus Dharma. Edisi Ketiga Jakarta : Erlangga.

Hidayati, Siti Noor. (2014). Pengaruh Kepemimpinan Transformasional Dan Transaksional Terhadap Kinerja Karyawan Dengan Komitmen Organisasi Sebagai "Intervening Variable”. Jurnal Maksipreneur. Vol III. No. 2. Juni 2014.

Luthans, F. (2016). Organizational Behaviour. Seven Edition. McGraw-Hil. Inc. Singapore.

Mas'ud, Machfoedz. (2014). Kewirausahaan. Metode. Manajemen. dan Implementasi. Yogyakarta : BPFE.

Mathis, R. L dan Jackson, J.H. (2010). Manajemen Sumber Daya Manusia. Buku I. Jakarta. PT. Salemba Embat Patria. 
Maulizar., Musnadi. S dan Yunus, M. (2012). Pengaruh Kepemimpinan Transaksional Dan Transformasional Terhadap Kinerja Karyawan Bank Syariah Mandiri Cabang Banda Aceh. Jurnal Ilmu Manajemen. ISSN 2302-0199 Pascasarjana Universitas Syiah Kuala.

Mubarak, Ahmad dan Darmanto, Susetyo. (2015). Pengaruh Gaya Kepemimpinan Transformasional Dan Budaya Organisasi Terhadap kinerja karyawan Dengan Komitmen Organisasi Sebagai Variabel Intervening (Studi pada PNS di Kecamatan Watukumpul Kabupaten Pemalang). Maksimum Vol.5 No.1 September 2015 - Februari 2016.

Nawawi, Hadari. (2013). Manajemen Sumber Daya Manusia untuk Bisnis yang Kompetitif. Yogyakarta: Gajah Mada University Press.

Nurdin, Sahidillah dan Rohendi, Acep. (2016). Gaya Kepemimpinan Transformasional. Budaya Organisasi. Dan Kinerja Karyawan Dengan Mediasi Komitmen Organisasi. Ecodemica. Vol. IV No.1 April 2016.

Robbins, S. (2018). Manajemen Dalam Kebijakan SDM. Edisi Revisi. Edisi Pertama. Jakarta: Bumi Aksara.

Sopiah. (2014). Perilaku Organisasional. Yogyakarta: Penerbit Andi

Subhi, Emil Ryan. (2014). Pengaruh Kepemimpinan Transformasional Terhadap Kinerja Karyawan Dengan Penghargaan Sebagai Variabel Moderating. Jurnal Ilmu dan Riset Manajemen Vol. 3 No. 2.

Wijaya, Muksin. (2015). Kepemimpinan Transformasional di Sekolah Dalam Meningkatkan. Jurnal Pendidikan Penabur. No.05/ Th.IV.Yukl, Gary. (2010). Leadership in Organization. Alih Bahasa: Sampe Maselinus dan Rita Tondok Andarika. Second Edition. New Jersey: Prentice-Hall. Inc. 